\title{
Pyrazole Derivatives with NCN Junction and their Biological Activity: A Review
}

\section{Farid Abrigach ${ }^{1 *}$ and Rachid Touzani ${ }^{1,2}$}

${ }^{1}$ Laboratory of Applied Chemistry and Environment (LCAE-URAC18), COSTE, Faculty of Science, University Mohammed the First, Oujda, Morocco ${ }^{2}$ Faculté Pluridisciplinaire de Nador BP300, Selouane 62702 Nador, Morocco

\begin{abstract}
Pyrazole derivatives have their own importance in aromatic organic heterocycle family. Application of these derivatives in chemistry and biology has attracted increasing interest occupy a unique place in field of medicinal chemistry due to their wide spectrum of biological activities. There are known for their anticancer, antiviral, antibacterial, antifungal, analgesic and anti-inflammatory and activities and so on. Due to the importance of this chemical skeletons, the present review reports the recent progress (2010-2016) on the biological activities of some monodentate, bidentate, tridentate and tetradente compounds based on pyrazole moieties and containing NCN bonds which connecting between the pyrazole and amine unit.
\end{abstract}

Keywords: Pyrazole; Bipyrazole; N-donor electron rich; Pharmacological activities

Abbreviations: DNA: Deoxyribonucleic Acid; $\mathrm{IC}_{50}$ : Half-maximal Inhibitory Concentration; MIC: Minimum Inhibitory Concentration; MTT: 3-(4,5-dimethythiazol-2-yl)-2,5-diphenyl tetrazolium bromide; SAR: Structure-Activity Relationship.

\section{Introduction}

In the course of searching for new drugs against diseases, the discovery, development and synthesis of new efficiency, active and less toxic molecules have been the object of many research works [1-5]. In this context, many structure of aromatic heterocyclic compounds have been investigated such as pyrazole [6], triazole [7] and tetrazole [8] due to the importance application of these skeletons in bioinorganic and medicinal chemistry [9-12]. In fact, more than $50 \%$ of all known organic compounds and most of the new drugs contain heterocyclic compounds [13]. In particular, heterocyclic compounds containing pyrazole moieties occupy a prominent place in this research due to their different and importance application in biology, pharmacology, industry and other sectors [14]. To date, a number of compounds containing pyrazole have been successfully commercialized, such as Celecoxib, Rimonabant, Sulfaphenazole and Penthiopyrad [15,16] (Figure 1).

The noun pyrazole was given for the first time by Ludwig Knorr in 1883 [17]. Pyrazole refers to the class of simple aromatic 5-membered ring, characterized by the presence of two double bonds, three carbon atoms and two nitrogen atoms in adjacent positions (Figure 2). These scaffolds are classified as alkaloids, although they are rare in nature. In 1959 , the first natural pyrazole, 1-pyrazolyl-alanine, was isolated from seeds of watermelons by Noe et Fowden [18].

The access to the pyrazolic systems has been extensively studied and many changes are made since the first syntheses described by Knorr [19] and Pechmann [20] (Scheme 1).

Recently, many other works have appeared and used by different research teams to prepare the substituted pyrazole cycle [21-28].

\section{Preparation of the NCN Pyrazolic Coumpounds}

The general method for the preparation of NCN junction pyrazolic compounds cited here is that reported previously in the literature without or after a modification of some reaction's conditions [2933]. All the compounds were prepared after a simple condensation between (3,5-dimethyl-1H-pyrazol-1-yl) methanol 1a, methyl 1-(hydroxymethyl)-5-methyl-1H-pyrazole-3-carboxylate $1 \mathrm{~b}$, ethyl 1-(hydroxymethyl)-5-methyl-1H-pyrazole-3-carboxylate 1c or (1H-pyrazol-1-yl) methanol 2 and various primary amines or diamines following the Scheme 2 below:

The all interest of these compounds is resumed in its sample and rapid pathway of synthesis adaptable to the user needs. Also, their structure presents a high importance in field of the organometallic chemistry. In fact, pyrazole containing ligands can be designed to be coordinated to metals through monodentate, bidentate, tridentate, and tetradente binding modes with various modifications of the ligand structure [34]. This strong efficiency capacity to complexing metals maybe due to the flexible $\mathrm{N}$-donor bridging of these receptors. In additions, it is the NCN bridge that making these receptors became more conformational changes, allowing the receptors to bend or rotate freely when interacting with metal centers so as to conform to the coordination geometries of metal ions [35].

\section{Biological Activities}

\section{Pyrazole as anticancer agents}

In previous work [36], we reported the synthesis of some novel compounds based on pyrazole and their anticancer activity against two tumor cell lines including breast (MDA-MB231) and colorectal (LoVo) cancers. We found that all these compounds present an antiproliferative activity against the two kind of the cell lines with varying $\mathrm{IC}_{50}$ values, which depended on the scaffold structure, the nature of the substituents and the sites of coordination of each compounds. We concluded that these compounds might therefore represent promising lead compounds for further development of anticancer drugs for human therapy (Scheme 3).

*Corresponding author: Farid Abrigach, Laboratory of Applied Chemistry and Environment (LCAE-URAC18), COSTE, Faculty of Science, University Mohammed the First, Oujda, Morocco, E-mail: abrigach.farid@live.fr

Received March 03, 2016; Accepted April 28, 2016; Published May 03, 2016

Citation: Abrigach F, Touzani R (2016) Pyrazole Derivatives with NCN Junction and their Biological Activity: A Review. Med chem (Los Angeles) 6: 292-298. doi:10.4172/2161-0444.1000359

Copyright: (c) 2016 Abrigach F, et al. This is an open-access article distributed under the terms of the Creative Commons Attribution License, which permits unrestricted use, distribution, and reproduction in any medium, provided the original author and source are credited. 


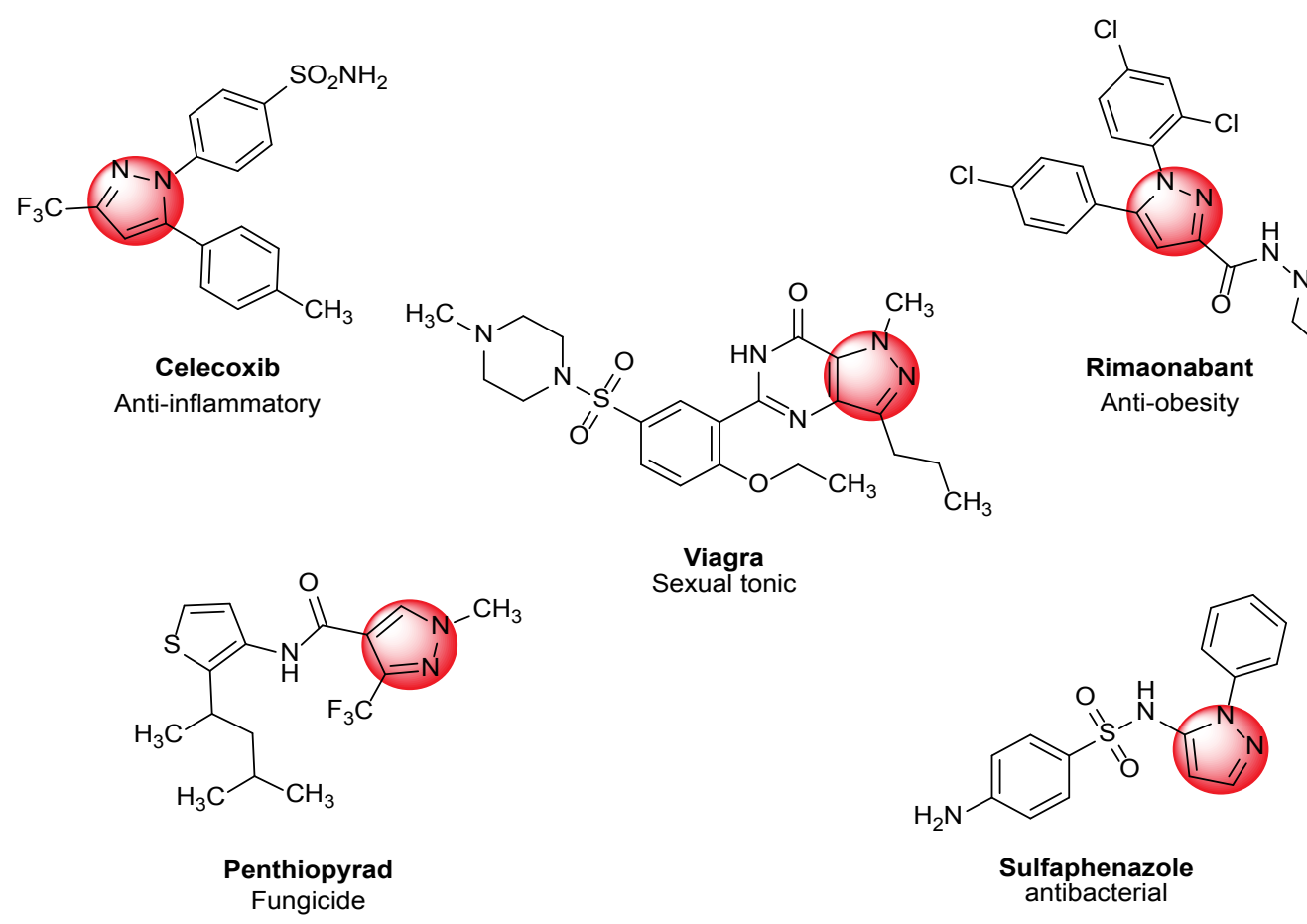

Figure 1: Some marketed pyrazolic compounds.

$$
1 H_{\text {-pyrazole }}
$$

Figure 2: Structure of pyrazole.

In other hand, Malek et al. [37] developed a new series of tridentate pyrazolic compounds and screened them for their cytotoxic activity against three tumor cell lines: human breast cancer cell line MDAMB231, human prostate cancer cell line PC3 and human colorectal cell line LoVo, using MTT assay. They found that two compounds had remarkable activity against the LoVo cell line with $\mathrm{IC}_{50}$ values equal to 8.5 and $9.3 \mu \mathrm{M}$ respectively (Scheme 4).

A novel series of some tridentate compounds based on (3,5-dimethyl-1H-pyrazol-1-yl)methanol and ethyl 1-(hydroxymethyl)-5-methyl-1H-pyrazole-3-carboxylate was prepared by Radi et al. [38]. Their anticancer activity was investigated against three kinds of cancer. The authors reported that most of these compounds exhibited a moderate antitumor activity against the three human cancer cell lines (Scheme 5).

\section{Pyrazole as antimicrobial agents}

A series of new amino acid ester functional pyrazolyl compounds was developed by Boussalah et al. [39] to evaluate their antifungal activity against Fusarium oxysporum $f$. sp. albedinis fungal and Saccharomyces cerevisiae yeast. The given compounds were found to exhibit a considerable activity against the two studied microorganisms (Scheme 6).
Bendaha et al. [40] synthesized a new pyrazolic compound (37) from 1a and a primary amine. The compounds $1 \mathrm{a}$ and 37 were investigated for their antifungal activity against Saccharomyces cerevisiae yeast. The results show that the both compounds had a toxic effect on the organism. They strongly suggest that this compound induce DNA damage and thus exert a different mechanism of action compared to other azole derivatives (Scheme 7).

The antibacterial and antifungal potential against two fungal strains (Saccharomyces cerevisiae and Fusarium oxysporum f. sp albedinis) and one bacterial strain (Echerichia coli) of the tridentate $24-29$ and four new pyrazolic derivatives 38, 39, 40 and 41 was reported by Radi et al. [41,42]. Based on the preliminary in vitro test results, the author concluded that some of these derivatives showed potent antimicrobial activity. Specially, the compounds 24, 26 and 28 (MIC=8.05, 8.08 and $7.05 \mu \mathrm{M}$ respectively). The SAR evaluation showed that the presence of an electron-attracting nitro group or a $+\pi$ electron effect ( 28 and 24 ) increase the activity. Whereas, the presence of an electron-donating methyl group decreases the activity (38 and 39). The two compounds 40 and 41 witch evaluated as acyclonucleoside analogues showed no antimicrobial activity against all the strains used in the test (Scheme 8).

In another study [43], we tested in vitro the compounds 3 -16 previously cited, against one fungal strain, namely Fusarium oxysporum $f$. sp. albedinis and three bacterial strains, namely Bacillus subtilis, Micrococcus luteus and Escherichia coli. The results showed that some compounds containing $(-\mathrm{OH})$ group and phenyl moiety have a considerable effect against tested bacteria and some compounds containing the (-Br) group have higher activity against tested fungal.

In our latest work [44], the synthesis and the antimicrobial effect of some new tetradente compounds based on pyrazole and primary diamines were studied. The antibacterial and antifungal test was carried 


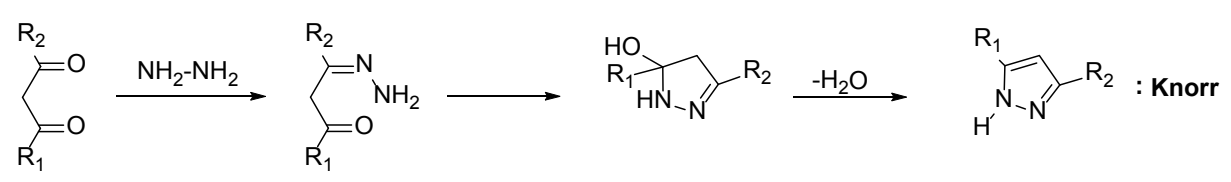

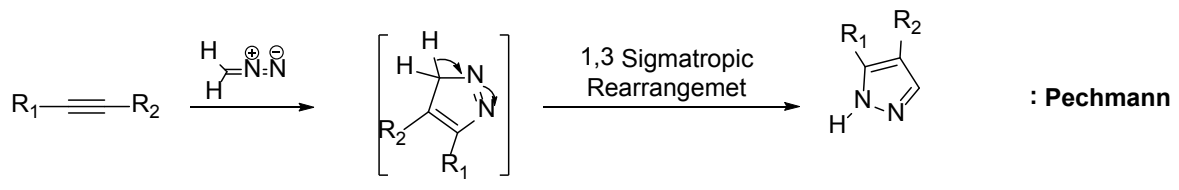

Scheme 1: General strategies for construction of pyrazole rings.
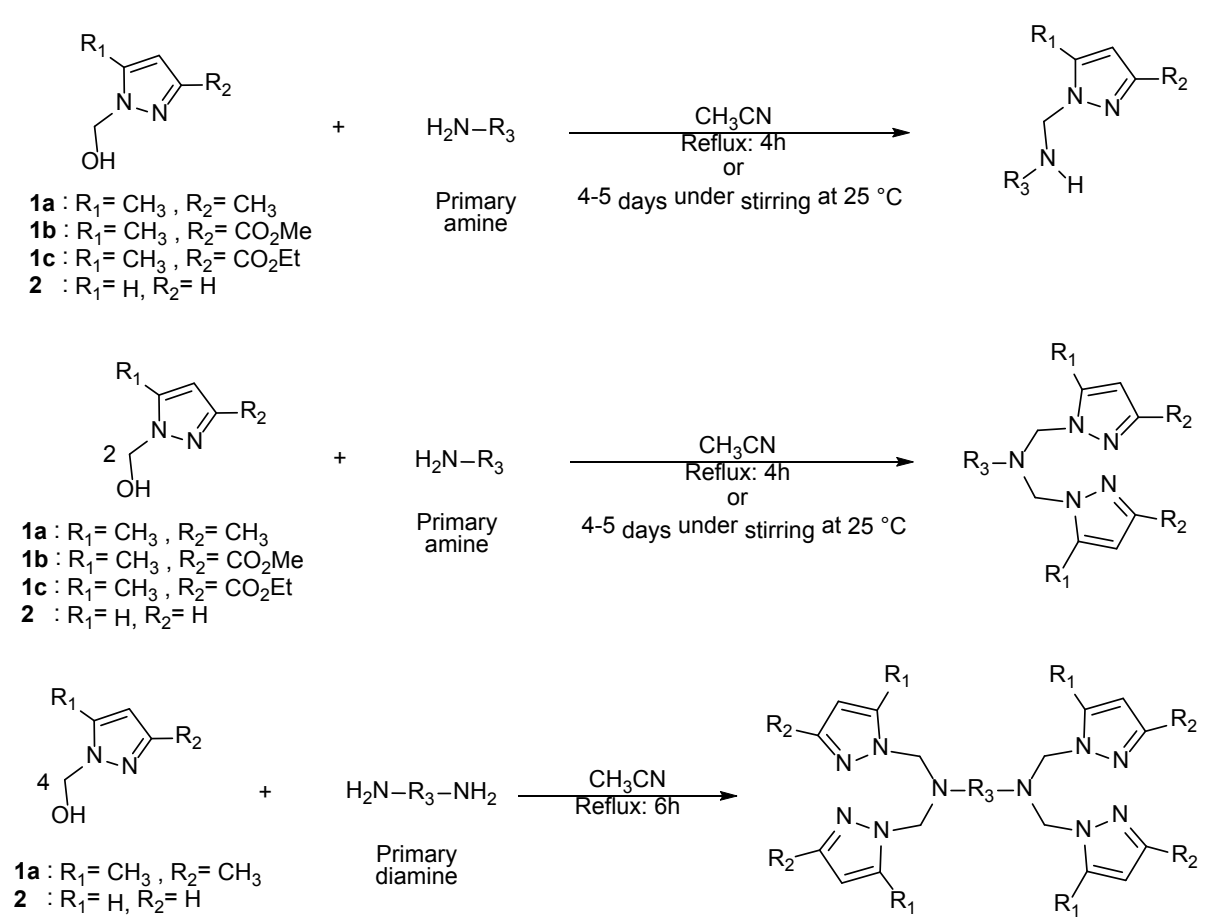

Scheme 2: General pathway of synthesized pyrazolic compounds.

out on Echerichia coli Bacterium and budding yeast Saccharomyces cerevisiae. All the compounds did not show any antibacterial activity against the gram negative strain when they were used at $500 \mu \mathrm{M}$. whereas, some synthetized compounds shown a strong inhibition rate on the budding yeast at $500 \mu \mathrm{M}$, especially the compound 46 (Scheme 9).

\section{Pyrazole as enzyme inhibitor agents}

Harit et al. [45] screened the two bipyrazolic tripodal compounds 17 and 20 against various hyperactive enzymes such as urease, b-glucuronidase, phosphodiesterase, a-chymotrypsin, acetylcholinesterase and butyrylcholinesterase. The two compounds were found to be selective inhibitors of urease with an $\mathrm{IC}_{50}$ values of 44.66 and $43.46 \mu \mathrm{M}$ respectively (vs. $21 \mu \mathrm{M} \mathrm{IC}_{50}$ for Thiourea which used as standard).

\section{Other Activities}

\section{Anticorrosion activity}

The inhibition of copper corrosion in aerated $3 \% \mathrm{NaCl}$ solution was investigated by Hammouti et al. [46] using potentiodynamic polarization and linear polarization resistance (LRP) in the presence of different concentrations of the bipyrazolic compound $\underline{\mathbf{5 3}}$. The tested compound was found to be efficient inhibitor of copper corrosion. Zarrouk et al. [47] studied the inhibition of the corrosion of carbon steel in $1 \mathrm{M}$ $\mathrm{HCl}$ solution by 2-[Bis-(3,5-dimethyl-pyrazol-1-ylmethyl)-amino]pentanedioic acid (54) using different methods. The results showed that the inhibition efficiency increase with increasing of inhibitor's concentration and decrease with the increase of temperature. In 2014 and 2015, we reported the inhibition efficiency of the compounds 7 , 8 and 48 , for mild steel corrosion in $1 \mathrm{M} \mathrm{HCl}$ solution [48,49], using weight loss measurement, potentiodynamic polarization curves and electrochemical impedance spectroscopy (EIS). A computational study was also made to calculate the quantum chemical parameters of the molecules using density functional theory (DFT) at B3LYP/6-31G (d,p) level (Scheme 10).

\section{Catecholase activity}

In 2015, Mouadili et al. [50] described the catalytic properties of complexes formed in situ with the compounds $6-8$ and $13-16$ and different metallic salts. The factors influencing the catecholase 


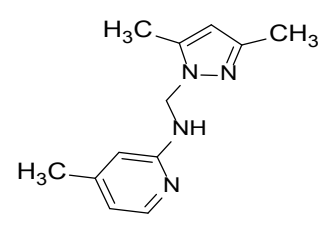

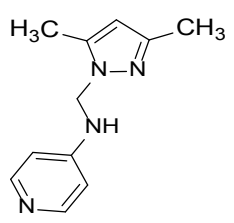
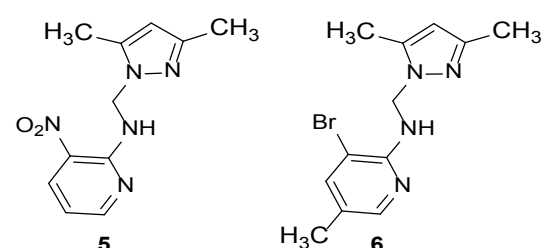<smiles>Cc1cc(C)n(CNc2ccc(Br)cn2)n1</smiles><smiles>Cc1cc(C)n(CNc2ncc(Br)cc2Br)n1</smiles><smiles>Cc1cc(O)nc(NCn2nc(C)cc2C)n1</smiles><smiles>CC(=O)c1ccc(NCn2nc(C)cc2C)cc1</smiles>

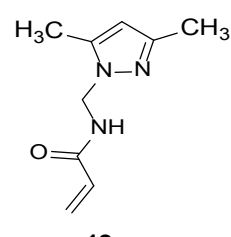

12<smiles>Cc1cc(C)n(Cc2nccc(O)n2)n1</smiles>

$13 \mathrm{OH}$<smiles>Cc1cc(C)n(CNCCc2ccccc2)n1</smiles><smiles>Cc1cc(C)n(CNCc2ccccc2)n1</smiles><smiles>Cc1ccnc(Cn2cccn2)c1</smiles>

Scheme 3: Molecular structure for the bidentate compounds tested.<smiles>[R7]c1cc(C)n(CN([R])Cn2nc([R7])cc2C)n1</smiles>

17: $\mathrm{R}_{1}=\mathrm{CH}_{3} \quad, \mathrm{R}_{2}=\mathrm{CH}_{2} \mathrm{CH}_{2} \mathrm{OH}$

$18: \mathrm{R}_{1}=\mathrm{CO}_{2} \mathrm{Me}, \mathrm{R}_{2}=\mathrm{CH}_{2} \mathrm{CH}_{2} \mathrm{OH}$

19: $\mathrm{R}_{1}=\mathrm{CO}_{2} \mathrm{Et}, \mathrm{R}_{2}=\mathrm{CH}_{2} \mathrm{CH}_{2} \mathrm{OH}$

$20: \mathrm{R}_{1}=\mathrm{CH}_{3} \quad, \mathrm{R}_{2}=\mathrm{C}_{6} \mathrm{H}_{11}$

21: $\mathrm{R}_{1}=\mathrm{CH}_{3} \quad, \mathrm{R}_{2}=\left(\mathrm{CH}_{2}\right)_{4} \mathrm{OH}$

22: $\mathrm{R}_{1}=\mathrm{CH}_{3} \quad, \mathrm{R}_{2}=\mathrm{CH}_{2} \mathrm{CHOHCH}_{3}$

$23: \mathrm{R}_{1}=\mathrm{CO}_{2} \mathrm{Et} \quad, \mathrm{R}_{2}=\mathrm{CH}_{2} \mathrm{CHOHCH}_{3}$

Scheme 4: Structures of the tridentate compounds.

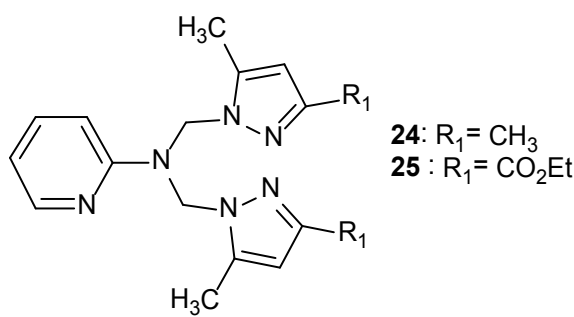<smiles>[R]c1cc(C)n(CN(Cn2nc([R])cc2C)c2ccccc2[R])n1</smiles>

26: $\mathrm{R}_{1}=\mathrm{CH}_{3}, \quad, \mathrm{R}_{2}=\mathrm{H}$

$27: \mathrm{R}_{1}=\mathrm{CO}_{2} \mathrm{Et}, \mathrm{R}_{2}=\mathrm{H}$

$29: \mathrm{R}_{1}=\mathrm{CO}_{2} \mathrm{Et}, \mathrm{R}_{2}=\mathrm{NO}_{2}$

Scheme 5: General structures of the tested compounds.

activity of these in situ complexes was investigated and the resultants showed that the highest rate of catechol oxidation was given by the combination formed by one equivalent of ligand 13 and two equivalents of $\mathrm{Cu}\left(\mathrm{CH}_{3} \mathrm{COO}\right)_{2}$ salt in THF as solvent $\left(\mathrm{V}=27.449 \mu \mathrm{mol}\right.$. $\left.\mathrm{L}^{-1} \mathrm{~min}^{-1}\right)$. 
<smiles>COC(=O)CN(Cn1nc(C)cc1C)Cn1nc(C)cc1C</smiles>

30<smiles>CCOC(=O)CN(Cn1nc(C)cc1C)Cn1nc(C)cc1C</smiles>

31<smiles>CCOC(=O)C(Cc1ccccc1)N(Cn1nc(C)cc1C)Cn1nc(C)cc1C</smiles><smiles>COC(=O)C(Cc1c[nH]c2ccccc12)N(Cn1nc(C)cc1C)Cn1nc(C)cc1C</smiles><smiles>COC(=O)C(C(C)C)N(Cn1nc(C)cc1C)Cn1nc(C)cc1C</smiles>

35<smiles>COC(=O)C(C)N(Cn1nc(C)cc1C)Cn1nc(C)cc1C</smiles>

36

Scheme 6: The tested Amino acid ester functional pyrazolyl compounds.

$\mathrm{H}_{3} \mathrm{C}$<smiles>Cc1cc(C)n(CO)n1</smiles><smiles>CN(C)CN</smiles>

$\mathrm{H}_{3} \mathrm{C}_{7}$

Scheme 7: Preparation of the compound 37.<smiles>Cc1cc(C)n(CN(Cn2nc(C)cc2C)c2ccccc2C)n1</smiles>

38<smiles>Cc1cc(C)n(CNCCO)n1</smiles>

40<smiles>CCOC(=O)c1cc(C)n(CN(Cn2nc(C(=O)OCC)cc2C)c2ccccc2C)n1</smiles>

39<smiles>CCOC(=O)c1cc(C)n(CNCCO)n1</smiles>

41
Scheme 8: The pyrazole derivatives screened.

In same area, Takfaoui et al. [51] found that the in situ copper (II) complexes formed by compounds 3 - 5 and $9-11$ are more efficient than those based on $\mathrm{NiCl}_{2}, \mathrm{Co}\left(\mathrm{NO}_{3}\right)_{2}$ and $\mathrm{ZnCl}_{2}$ salts.<smiles>CCN(CC)CCCN(Cn1nc(C)cc1C)Cn1nc(C)cc1C</smiles>

37

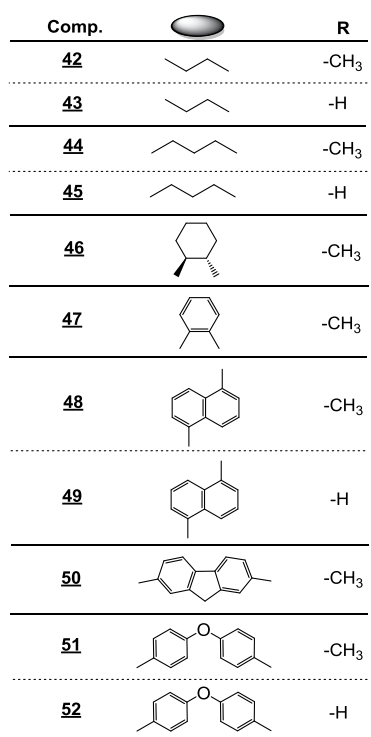

Scheme 9: Structure of the tetradente compounds tested. 
<smiles>COc1cc(C)n(CN(Cn2nc(C(C)=O)cc2C)C2CCCCC2)n1</smiles>

53

Scheme 10: Bipyrazolic Compounds 53 and 54<smiles>C=Cc1ccc(N(Cn2nc(C)cc2C)Cn2nc(C)cc2C)cc1</smiles>

Scheme 11: Bipyrazolic tripod ligands used.

\section{Extractive activity}

Using liquid-liquid extraction process, Khoutoul et al. [52] investigated the capacity of the compounds $3,5,6,9,10,15$ to extract $\mathrm{Cu}^{2+}, \mathrm{Cd}^{2+}, \mathrm{Pb}^{2+}, \mathrm{Co}^{2+}, \mathrm{Ni}^{2+}, \mathrm{Zn}^{2+}$ and $\mathrm{Fe}^{2+}$ ions from aqueous solutions. The authors found that all the ligand except 15 have a high affinity and excellent efficiency to extract the bivalent $\mathrm{Fe}^{2+}$ ion. A theoretical study was also made and the results showed that the extractive activity towards $\mathrm{Fe}^{2+}$ ions increases with decreasing in molecular stability. In other hand, Harit et al. [53] reported The complexing properties of ligands $\underline{\mathbf{5}}-\underline{\mathbf{5 8}}$ towards bivalent metal cations $\left(\mathrm{Hg}^{2+}, \mathrm{Cu}^{2+}, \mathrm{Pb}^{2+}\right.$ and $\left.\mathrm{Cd}^{2+}\right)$ and alkaline metal ions $\left(\mathrm{Na}^{+}, \mathrm{Li}^{+}\right.$and $\left.\mathrm{K}^{+}\right)$. The ligands were found to be more selective to extract transition metal cations, especially mercury, copper and lead (Scheme 11).

\section{Conclusion}

As seen on most of this paper, pyrazole moiety is a unique template that associated with several biological activities. This review highlightened research work of many researchers reported in literature that presented comprehensive details of pyrazole analogues and its pharmacological activity. The authors demonstrated that the efficiency of their compounds is very depended on the scaffold structure and the nature of the substituents groups on each one. But in fact, more investigations are needed and must be carried out to evaluate more activities of pyrazole and its derivatives for many diseases whose treatment are difficult in the medical sciences.

\section{Acknowledgements}

We are grateful to all our collaborators for their contributions to part of the data summarized here.

\section{References}

1. Kokila P, Sarju P, Rinku P, Rekha P (2011) A Simple and Efficient Procedure for Synthesis of Biologically Active 1,2,4-Triazolo-[3,4-b]-1,3,4-thiadiazole -2-arylthiazolidine-4-one Derivatives. Res. J. Chem. Sci. 1: 18-24.

2. Mulongo G, Mbabazi J, Nnamuyomba P, Mpango GB (2011) Further Biologically Active Derivatives of 1, 3-Diketones. Res J Chem Sci 1: 80-84.
3. Dalvi SN, Garge SS (2011) Synthesis and Biological activity for 4-Methoxyphenyl (pyrazin-2-yl) Methanone and its detection by GC-MS Techniques. Res. J. Chem. Sci. 1: 85-87.

4. George M, Jolocam M, Odongkara B, Twinomuhwezi H, Mpango GB (2011) New Biologically Active Compounds from 1, 3-Diketones. Res J Chem Sci 1: 102-108.

5. Rakhi C, Shelly (2011) Synthesis, Spectral and Pharmacological Study of $\mathrm{Cu}(\mathrm{II}), \mathrm{Ni}(\mathrm{II})$ and $\mathrm{Co}(\mathrm{II})$ Coordination Complexes. Res J Chem Sci 1: 1-5.

6. Bol JE, Driessen WL, Reedijk J (1995) Synthesis and crystal structure of a dinuclear copper(II) complex with a novel tetrapyrazolyl macrocycle. J Chem Soc Chem Commun, pp: 1365-1366.

7. Fernández-Lázaro F, Mendoza JD, Mó O, Rodríguez-Morgade S, Torres T, et al. (1989) Phthalocyanine analogues: Synthesis, spectroscopy, and theoretical study of 8,18-dihydrodibenzo[b,I]-5,7,8,10,15,17,18,20-octa-azaporphyrin and MNDO calculations on its related Huckel heteroannulene. J Chem Soc Perkin Trans 2: 797-803.

8. Perez MA, Bermejo JM (1993) Synthesis of multidentate 1,3,4-oxadiazoleimine-, and phenol-containing macrocycles. J Org Chem 58: 2628-2630.

9. Trofimenko S (1972) Coordination chemistry of pyrazole-derived ligands. Chem Rev 72: 497-509.

10. Trofimenko S (1986) The Coordination Chemistry of Pyrazole-Derived Ligands In Prog Inorg Chem Lippard SJ, Edn John Wiley \& Sons, Inc. Hoboken, NJ USA 34: 115-210.

11. Zeglis BM, Pierre VC, Barton JK (2007) Metallo-intercalators and metalloinsertors. Chem Commun (Camb) : 4565-4579.

12. Gupta T, Dhar S, Nethaji M, Chakravarty AR (2004) Bis(dipyridophenazine) copper(II) complex as major groove directing synthetic hydrolase. Dalton Trans : 1896-1900.

13. Saini MS, Kumar A, Dwivedi J, Singh R (2013)A review: Biological significances of heterocyclic compounds. Int J Pharma Sci Res 4: 66-77.

14. Jamwal A, Javed A, Bhardwaj V (2013) A review on Pyrazole derivatives of pharmacological potential. J Pharm BioSci 1: 114-123.

15. Shan G, Liu P, Rao Y (2011) A new synthesis of pyrazoles through a Lewis acid catalyzed union of 3-ethoxycyclobutanones with monosubstituted hydrazines. Org Lett 13: 1746-1749.

16. Fustero S, Simón-Fuentes A, Sanz-Cervera JF (2009) Recent Advances in the Synthesis of Pyrazoles: A Review. Org Prep Proced Int 41: 253-290.

17. Evelyn CS (2012) Pyrazole: Composé organique. Hétérocycle, Aromaticité, Atome, Carbone, Azote. Fec Publishing

18. Schröter HB, Neumann D, Katritzky AR, Swinbourne FJ (1966) Withasomnine, A pyrazole alkaloid from Withania somnifera Dun. Tetrahedron 22: 2895-2897.

19. Knorr $L$ (1883) Einwirkung von Acetessigester auf Phenylhydrazin. Ber Dtsch Chem Ges 16: 2597-2599.

20. Pechmann H (1898) Pyrazol aus Acetylen und Diazomethan. Ber Dtsch Chem Ges 31: 2950-2951.

21. Sun A, Ye J-H, Yu H, Zhang W, Wang X (2014) A new efficient synthesis of pyrazoles from hydrazonoyl halides and $ß$-oxophosphonates. Tetrahedron Lett 55: 889-892.

22. Kong Y, Tang M, Wang Y (2014) Regioselective synthesis of 1,3,5-trisubstituted pyrazoles from $\mathrm{N}$-alkylated tosylhydrazones and terminal alkynes. Org Lett 16: 576-579.

23. Raji Reddy C, Vijaykumar J, Grée R (2013) Facile One-Pot Synthesis of 3,5-Disubstituted 1H-Pyrazoles from Propargylic Alcohols via Propargyl Hydrazides. Synthesis 45: 830-836.

24. Zhang G, Ni H, Chen W, Shao J, Liu H, et al. (2013) One-pot three-component approach to the synthesis of polyfunctional pyrazoles. Org Lett 15: 5967-5969.

25. Sha Q, Wei Y (2013) An Efficient One-Pot Synthesis of 3,5-Diaryl-4bromopyrazoles by 1,3-Dipolar Cycloaddition of In Situ Generated Diazo Compounds and 1-Bromoalk-1-ynes. Synthesis 45: 413-420.

26. Panda N, Jena AK (2012) Fe-catalyzed one-pot synthesis of 1,3-di- and $1,3,5$-trisubstituted pyrazoles from hydrazones and vicinal diols. J Org Chem 77: $9401-9406$.

27. Hu J, Chen S, Sun Y, Yang J, Rao Y (2012) Synthesis of tri- and tetrasubstituted 
Citation: Abrigach F, Touzani R (2016) Pyrazole Derivatives with NCN Junction and their Biological Activity: A Review. Med chem (Los Angeles) 6: 292-298. doi:10.4172/2161-0444.1000359

pyrazoles via $\mathrm{Ru}(\mathrm{II})$ catalysis: intramolecular aerobic oxidative $\mathrm{C}-\mathrm{N}$ coupling Org Lett 14: 5030-5033.

28. Chen H, Wu L-L, Ge Y-C, He T, Zhang L (2012) An Efficient One-Pot Synthesis of 3,5-Disubstituted 1H-Pyrazoles. Synthesis 44: 1577-1583.

29. Dvoretzky I, Richter GH (1950) Formaldehyde Condensation in the Pyrazole Series. J Org Chem 15: 1285-1288.

30. Touzani R, Ramdani A, Ben-Hadda T, El Kadiri S, Maury O, et al. (2001) Efficient Synthesis of New Nitrogen Donor Containing Tripods under Microwave Irradiation and without Solvent. Synth Commun 31: 1315-1321.

31. Touzani R, Garbacia S, Lavastre O, Yadav VK, Carboni B (2003) Efficien solution phase combinatorial access to a library of pyrazole- and triazolecontaining compounds. J Comb Chem 5: 375-378.

32. Driessen WL (1982) Synthesis of some new pyrazole-containing chelating agents. Recl Trav Chim Pays-Bas 101: 441-443.

33. Kim S, Kim D, Lee HJ, Lee H (2014) Synthesis, structural features, and methy methacrylate polymerisation of binuclear zinc (II) complexes with tetradentate pyrazolyl ligands. J Mol Struct 1063: 70-76.

34. Choi S, Kim S, Lee H-J, Lee H (2014) Cadmium(II) complexes containing N'substituted N,N-bispyrazolyl ligands: The formation of 4- and 5-coordinated monomers versus 6-coordinated dimer. Inorg Chem Commun 44: 164-168.

35. Luo YH, Wu GG, Mao SL, Sun BW (2013) Complexation of different metals with a novel $\mathrm{N}$-donor bridging receptor and Hirshfeld surfaces analysis. Inorg Chim Acta 397: 1-9.

36. Abrigach F, Khoutoul M, Benchat N, Radi S, Draoui N, et al. (2014) Library of Synthetic Compounds Based on Pyrazole Unit: Design and Screening Against Breast and Colorectal Cancer. Lett Drug Des Discovery 11: 1010-1016.

37. Malek F, Draoui N, Feron O, Radi S (2013) Tridentate bipyrazole compounds with a side-arm as a new class of antitumor agents. Res Chem Intermed 40 : 681-687.

38. Radi S, Toubi Y, Draoui N, Feron O, Riant O (2012) One Pot Synthesis and In vitro Antitumor Activity of some Bipyrazolic Tripodal Derivatives. Lett Drug Des Discovery 9: 305-309.

39. Boussalah N, Touzani R, Souna F, Himri I, Bouakka M, et al. (2013) Antifungal activities of amino acid ester functional pyrazolyl compounds against Fusarium oxysporum f. sp. albedinis and Saccharomyces cerevisiae yeast. J Saudi Chem Soc 17: 17-21.

40. Bendaha H, Yu L, Touzani R, Souane R, Giaever G, et al. (2011) New azole antifungal agents with novel modes of action: synthesis and biological studies of new tridentate ligands based on pyrazole and triazole. Eur J Med Chem 46 4117-4124.

41. Radi S, Toubi Y, Hamdani I, Hakkou A, Souna F, et al. (2012) Synthesis,
Antibacterial and Antifungal Activities of some new Bipyrazolic Tripodal Derivatives. Res J Chem Sci 2: 40-44.

42. Radi S, Salhi S, Radi A (2010) Synthesis and Preliminary Biological Activity of Some New Pyrazole Derivatives as Acyclonucleoside Analogues. Lett Drug Des Discovery 7: 27-30.

43. El-Youbi M, Benabbes R, Lahmassi I, Abrigach F, Khoutoul M, et al. (2015) Antibacterial and antifungal activities of new pyrazolic compounds. Moroccan J Biol 12: 9-13

44. Abrigach F, Bouchal B, Riant O, Mace Y, Takfaoui A, et al. (2016) New N,N,N',N'tetradentate Pyrazoly Agents: Synthesis and Evaluation of their Antifungal and Antibacterial Activities. Med Chem 12: 83-89.

45. Harit T, Malek F, Bali BE, Khan A, Dalvandi K, et al. (2011) Synthesis and enzyme inhibitory activities of some new pyrazole-based heterocyclic compounds. Med Chem Res 21: 2772-2778.

46. Hammouti B, Dafali A, Touzani R, Bouachrine M (2012) Inhibition of copper corrosion by bipyrazole compound in aerated $3 \% \mathrm{NaCl}$. J Saudi Chem Soc 16: $413-418$.

47. Zarrouk A, Zarrok H, Salghi R, Bouroumane N, Hammouti B, et al. (2012) The Adsorption and Corrosion Inhibition of 2-[Bis-(3,5-dimethyl-pyrazol-1-ylmethyl)amino]-pentanedioic Acid on Carbon Steel Corrosion in $1.0 \mathrm{~m} \mathrm{HCl}$. Int J Electrochem Sci 7: 10215 - 10232.

48. Ismaily Alaoui K, El Hajjaji F, Azaroual M, Taleb M, Chetouani A, et al (2014) Experimental and quantum chemical studies on corrosion inhibition performance of pyrazolic derivatives for mild steel in hydrochloric acid medium, correlation between electronic structure and inhibition efficiency. J Chem Pharm Res 6: 63-81.

49. ELouadi Y, Abrigach F, Bouyanzer A, Touzani R, Riant O, et al. (2015) Corrosion inhibition of mild steel by new $\mathrm{N}$-heterocyclic compound in $1 \mathrm{M} \mathrm{HCl}$ Experimental and computational study. Der Pharma Chemica 7: 265-275.

50. Mouadili A, Abrigach F, Khoutoul M, Zarrouk A, Benchat N, et al. (2015) Biomimetic oxidation of catechol employing complexes formed in-situ with $\mathrm{NH}$ pyrazole ligands and transition metallic salts. J Chem Pharm Res 7: 968-979.

51. Takfaoui A, Bouabdallah I, Abrigach F, Khoutoul M, Benchat N, et al. (2013) New $\mathrm{N}$-alkylated pyrazolyl derivatives for catecholase catalytic properties. Mor J Chem 1: 11-17.

52. Khoutoul M, Abrigach F, Zarrouk A, Benchat N-E, Lamsayah M, et al. (2015) New nitrogen-donor pyrazole ligands for excellent liquid-liquid extraction of $\mathrm{Fe}^{2+}$ ions from aqueous solution, with theoretical study. Res Chem Intermed 41: 3319-3334.

53. Harit T, Cherfi M, Isaad J, Riahi A, Malek F (2012) New generation of functionalized bipyrazolic tripods: synthesis and study of their coordination properties towards metal cations. Tetrahedron 68: 4037-4041. 